\title{
Strategies of physics learning based on traditional games in senior high schools during the Covid-19 pandemic
}

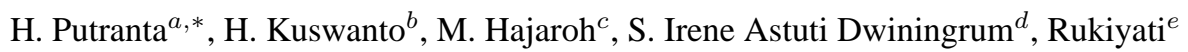 \\ ${ }^{a}$ Concentration of Physics Education, Department of Educational Sciences, Graduate School, \\ Yogyakarta State University, Yogyakarta, 55281, Indonesia. \\ *e-mail: himawanputranta.2020@student.uny.ac.id \\ ${ }^{b}$ Department of Physics Education, Faculty of Mathematics and Natural Sciences, \\ Yogyakarta State University, Yogyakarta, 55281, Indonesia. \\ ${ }^{c, d, e}$ Department of Educational Philosophy and Sociology, Faculty of Educational Sciences, \\ Yogyakarta State University, Yogyakarta 55281, Indonesia.
}

Received 7 July 2021; accepted 12 July 2021

\begin{abstract}
Physics learning during the Covid-19 pandemic must still be done so that students can still get physics intake. This phenomenological research aims to explore physics teacher strategies in conducting traditional game-based learning in senior high schools during the Covid-19 pandemic. The research data was collected through in-depth interviews with 10 physics teachers from five senior high schools in Yogyakarta. The ten participants were taken using the purposive sampling technique. The data analysis used analytic reduction which started with identifying important statements from the interview results, determining the core theme, and interpreting the physics learning strategy essence. The research results found that traditional game-based physics learning was carried out using contextual, inquiry, project, and problem-based learning models. The physics material is integrated into traditional games which include tulup, benthik, bekelan, sulamanda, egrang, sekongan, jeblugan, and gobak sodor. Physics learning evaluation is carried out by assessing assignments, performance, presentations, tests, and the results of making students' traditional games. Traditional game-based physics learning is done through distance learning applications such as Zoom, Google Meet, Google Classroom, Google Mail, and WhatsApp. Supporting factors for learning physics based on traditional games include efficient learning, learning can be done anywhere, and students can explore their abilities widely. Inhibiting factors for learning physics based on traditional games include unstable internet networks, students' different abilities, and never done distance learning. The physics teacher's competence, the student's abilities, and the facilities availability are the main factors in determining the learning physics success based on traditional games during the Covid-19 pandemic.
\end{abstract}

Keywords: Covid-19 pandemic; distance learning physics; integrated learning; learning strategies; traditional games.

DOI: https://doi.org/10.31349/RevMexFisE.19.010207

\section{Introduction}

Education is the main key to moving the nation's progress, both in terms of morals, culture, science, and technology. Without quality education, it will hurt the quality of the human resource [1]. Especially now that the world is experiencing a Covid-19 pandemic, which affects all sectors, including the education sector. The Covid-19 pandemic has limited interaction between humans. This also happens in the learning process that occurs in schools. Learning that was initially face-to-face between teachers and students was then carried out remotely [2]. Distance learning is learning that is carried out not face to face, but through intermediary media. Distance learning is a learning innovation that aims to create learning that is efficient, effective, and can be done anywhere [3]. Before the Covid-19 pandemic, the distance learning idea had been discussed by education practitioners. The initial idea underlying the emergence of distance learning is that face-to-face learning is increasingly ineffective [4]. Face-toface learning requires a variety of physical means that must be fulfilled. This causes learning to be ineffective, so there is a need for learning innovations.
Distance learning is carried out with different supporting facilities from face-to-face learning. Distance learning is carried out using various online learning classroom applications. Apart from requiring learning applications, distance learning also requires other supporting facilities such as computers, laptops, and smartphones that are supported by a stable internet network [5]. However, not all students have adequate supporting facilities. Many students do distance learning by borrowing neighbor's laptops and unstable internet signals [6]. Some of these things are certainly a challenge for students, teachers, and parents to support distance learning implementation. Moreover, not all students have the same technological literacy skills, so that distance learning is hampered [7]. Distance learning is still carried out to produce quality students despite all the limitations that exist. Distance learning in Indonesia began to be carried out comprehensively and simultaneously during the Covid-19. Before the Covid-19 pandemic, learning in high schools, especially in physics, was carried out face to face [8].

In addition to creating quality students, learning during the Covid-19 pandemic was carried out remotely to realize meaningful learning. Meaningful learning is learning that 
provides deep meaning to students to be able to apply the learning material they are learning into life [9]. Meaningful learning can be done by focusing on learning on students. In other words, meaningful learning can be created if students act as the main subject of learning [10]. By carrying out meaningful learning, students can improve their problem-solving abilities [11]. Besides, meaningful learning can improve students' critical and creative thinking skills [12]. Students can increase their sensitivity and concern for all events that occur in their lives [13]. One of the efforts made by teachers and students in conducting distance learning physics to achieve meaningful learning is by integrating it into the phenomena that occur in life such as through traditional games.

Traditional games are a phenomenon that is often found in students' lives. Traditional games are a form of local wisdom that is owned by the community to show the existence of their culture to other communities [14]. Traditional games are reactive activities that serve as a means of recreation. Thus, traditional games are a form of manifestation of certain regional local wisdom which serves as a differentiator from other regions. Apart from being a differentiator from other areas, traditional games are also suitable for forming good character in children [15]. This is because traditional games contain moral messages that help develop children's cognition, psychomotor, and personality. Traditional games can optimize cognitive and motoric aspects of children, strengthen solidarity, and respect each other [16]. Traditional games contain a variety of physics concepts. The physics concepts contained in traditional games go from the manufacturing process to the process of playing traditional games.

One of the traditional games that children often play is the bamboo shooting game [17]. This bamboo shooting game has various physics concepts in it, both during the manufacturing process until the process of playing it. Furthermore, traditional games that people have in a country, especially Indonesia, are not limited to one kind of traditional game. Indonesia is the largest archipelagic country in the world that has a variety of traditional games. This is like what is owned by the Special Region of Yogyakarta, which not only has bamboo shooting games, but has other traditional games such as gobak sodor, namely the game of knocking down opponents on the track and sulamanda, which is a game of jumping in a pattern [18]. These traditional games can be integrated into physics learning because they contain complex physics concepts. By integrating physics learning into traditional games, one can improve students' conceptual understanding [19]. Students can improve critical thinking skills when studying physics which is integrated into traditional games [20]. By integrating embroidery games, students can improve their problem-solving skills. The integration of traditional games into physics learning can strengthen students' awareness of problems in life.

Although traditional games contain physics concepts, there are obstacles in learning physics based on traditional games. Teachers rarely do physics learning integrated into traditional games [21]. Most teachers teach physics material to students textually [22]. Physics learning is appropriately done by integrating it into the daily experiences of students through discovery activities or projects. There are many reasons behind the lack of integration of physics learning into traditional games. Besides teachers who teach physics textually, teachers also have difficulty applying physics to traditional games [23]. The teacher wants physics learning to be done quickly because there is a lot of physics material taught. Teachers are used to teaching physics by doing practice questions on printed books [24].

Constraints that occur in integrating physics learning into traditional games make it difficult for students to integrate physics concepts into life [25]. Besides, students find it difficult to learn physics and even often misconceptions appear in students [26]. Although most teachers do not integrate traditional games into physics learning, there are still some teachers in Yogyakarta who integrate them. This is by the research findings that physics teachers in Yogyakarta have integrated benthik games (a kind of game like softball using a wooden stick) into physics learning about Newton's law of motion [27]. Learning physics that integrates benthik games about Newton's law of motion can provide a high sense of enthusiasm for students. Students become more critical when participating in learning as evidenced by the number of students asking for the physics concepts contained in benthik games [28]. Therefore, there needs to be habituation on an ongoing basis in integrating traditional games into physics learning.

\subsection{Research problems}

Various problems always arise in education, especially in the current conditions that are being hit by the Covid-19 pandemic. Learning was initially face-to-face, but the Covid19 pandemic has led to distance learning. Distance learning physics does not only require writing tools, but requires supporting equipment which includes laptops, smartphones, and a stable internet signal [5]. Distance learning support equipment must be owned by students so that they can continue to learn. However, many students experience problems in participating in distance learning due to limited supporting equipment. Not all students have the same technological literacy skills, so that distance learning is hampered [29]. Besides, physics learning experiences several obstacles that have been experienced by teachers and students. Physics learning should be done by integrating phenomena that occur in life such as traditional games, but rarely integrate them into these situations. This of course affects the ability of students to apply the physics concepts they have learned into life. Therefore, physics learning based on traditional games needs to be done to improve students' understanding of the concepts of physics. Make it easy for students to apply physics concepts to life and become meaningful solution for distance learning physics. 


\subsection{Research question}

Based on the problems previously described, various problems occurred in distance learning during the Covid-19 pandemic. Physics learning is still rarely integrated into traditional games. Although there have been several solutions carried out by physics teachers when overcoming these problems, a more in-depth exploration of the strategies undertaken by high school physics teachers in conducting traditional game-based learning during the Covid-19 pandemic is needed. Thus, the questions to be answered in this research are as follows.

1. What was the strategy of high school physics teachers in learning physics based on traditional games during the Covid-19?

2. What are some traditional games that can be integrated into physics learning during the Covid-19 pandemic?

3. What are the supporting and inhibiting factors for learning physics based on traditional games in high schools during the Covid-19 pandemic?

\subsection{Research focus}

This research focuses on finding out the strategies employed by high school physics teachers in learning physics based on traditional games during the Covid-19 pandemic.

\section{Method}

\subsection{General background}

This qualitative research with a phenomenological method. This research was conducted to explore the strategies of physics teachers in carrying out traditional game-based learning in high schools during the Covid-19 pandemic. A more detailed objective of this research is to obtain in-depth information on how to teach high school physics teachers integrated with traditional games during the Covid-19 pandemic. Besides, this research is also to explore traditional games that can be integrated into physics learning as well as supporting and inhibiting factors for learning physics based on traditional games in high schools during the Covid-19 pandemic. This research was conducted for two months, from November to December 2020. This research is expected to be a guide in conducting further research, especially in the research theme of learning physics during the Covid-19 pandemic and learning physics based on traditional games.

\subsection{Participants}

Participants involved in this research were public high school physics teachers in Yogyakarta, Indonesia. Given many public senior high schools in Yogyakarta, the determination of the participants involved in this research used a purposive sampling technique. Purposive sampling technique is a technique used in taking research participants which is not random, but participants are drawn based on certain criteria [30]. The criteria determined in taking the participants were all physics teachers teaching in public high schools and all physics teachers had delivered physics material by integrating it into traditional games. Furthermore, the participants involved in this research were ten teachers from five public senior high schools in Yogyakarta. In other words, every public high school was selected by two physics teachers who had delivered physics material by integrating it into traditional games. The selection of ten participants in this phenomenological research is based on the stipulation that the number of participants allowed in phenomenological research is 3 to 15 heterogeneous participants [31]. Each high school participant is selected from one male and one female physics teacher.

In addition, another reason for choosing two teachers from each school was because of the five schools studied, only two to three teachers were found who often teach physics to their students through traditional games, both during normal conditions and the Covid-19 pandemic. Therefore, to uniform the number of participants from each school, it was decided that the participants in this research were two teachers, male, and female, from each school who often taught physics to their students through the help of traditional games, both during normal conditions and amid the Covid19 pandemic. The reason for the uniformity of the number of participants involved in this research is so that there is no difference in the gender proportion of participants from each school studied. Meanwhile, each teacher involved in this research taught physics to 60 to 120 students. The age range of students who were taught by the teachers who participated in this study was between 16 to 17 years. The profile of the participants involved in this phenomenological research can be seen in Table I.

Based on Table I, it is shown that all participants in this phenomenological research are anonymized. This is done by applicable research ethics to protect the confidentiality of participants and affiliates. Besides, giving each participant and

TABLE I. Participants in the phenomenological research.

\begin{tabular}{cccccc}
\hline No. & Name & Affiliation & \multicolumn{2}{c}{ Gender } & Total \\
& & & Male & Female & Students \\
\hline 1. & FA & PSHS-1 & 1 & - & 90 \\
2. & WA & PSHS-1 & - & 1 & 60 \\
3. & FB & PSHS-2 & 1 & - & 100 \\
4. & WB & PSHS-2 & - & 1 & 120 \\
5. & FC & PSHS-3 & 1 & - & 70 \\
6. & WC & PSHS-3 & - & 1 & 65 \\
7. & FD & PSHS-4 & 1 & - & 75 \\
8. & WD & PSHS-4 & - & 1 & 90 \\
9. & FE & PSHS-5 & 1 & - & 85 \\
10. & WE & PSHS-5 & - & 1 & 90 \\
\hline
\end{tabular}

Note: the participant's number was 10 participants. 
its affiliates initial names also aims to maintain the confidentiality of the information obtained. Participants involved in this research used their initials with their names disguised, including FA, WA, FB, WB, FC, WC, FD, WD, FE, and WE. Besides, the affiliations of the teaching participants' origins were also disguised, consisting of PSHS-1, PSHS-2, PSHS3, PSHS-4, and PSHS-5. The selection of participants from these five public senior secondary schools was made because these five schools were ranked in the top ten as the best schools in Yogyakarta.

\subsection{Instruments and procedures}

Data collection in this phenomenological research was carried out using in-depth interview techniques. To obtain quality interview results, when interviewing participants, interview guidelines were presented, and the interview process was recorded [32]. The questions posed to each participant in this interview process are open and general, designed to explore the phenomenon of learning physics based on traditional games in high schools during the Covid-19 pandemic. Interviews are conducted for forty to sixty minutes. Interviews were conducted not only in schools where the participants taught but were carried out wherever they agreed. Interviews were conducted by applying health protocols which included maintaining distance, wearing masks, and washing hands. The interview was conducted in a conducive atmosphere, so that participants could answer any questions posed freely and comfortably. Some participants did not wish to be interviewed directly, so interviews were conducted by telephone. An interview guide that contains a list of questions that were sent to participants to answer online.

Furthermore, in this in-depth interview, an interview guide was also prepared, containing a list of questions answered by the participants. The interview guide that has been compiled contains eleven questions that are asked to the participants. The first question is a prefix that contains questions such as name, length of teaching, and teaching experience. The next ten questions are the main questions of this phenomenological research. Do the other ten questions include what physics learning strategy did you do during the Covid-19 pandemic? Have you ever integrated traditional games into physics learning? What is the strategy you do in integrating traditional games into learning physics? What are the subjects of physics that are integrated into traditional games? What traditional games have you integrated into learning physics? What learning models do you use in integrating traditional games into physics learning? What is the general response of students in following physics lessons during the Covid-19 pandemic? What is the response of students in following physics learning integrated with traditional games during the Covid-19 pandemic? What are the factors that support the implementation of physics learning integrated with traditional games during the Covid-19 pandemic? What were the factors that hindered the implementation of physics learning integrated with traditional games during the
Covid-19 pandemic? The collected interview data was then analyzed using the analytical reduction method.

\subsection{Data analysis technique}

Before doing data analysis, the data that has been collected is tested for validity and reliability. The validity test is carried out by clarifying and reconfirming the data that has been obtained from the participants. The reliability test was carried out by asking the participants again the questions contained in the interview guide at different times. If the data obtained in the validity and reliability tests are the same as the data obtained during the first interview with the participants, then the data collected will be valid and reliable. After the data obtained is valid and reliable, the next step is to analyze the data. The data analysis used in this phenomenological research used the analytical reduction method. The stage of analytic reduction begins with identifying important statements from interviews, determining core themes based on interview results, and interpreting the essence of physics learning strategies that appear in phenomena in a holistic manner [33]. The point of the essence interpretation is to deeply interpret phenomenon that is being experienced and the response of participants in dealing with this phenomenon.

The data analysis procedure begins with changing the voice recordings from the interview results in a transcript of the interview results, making it easier to check the information that has been obtained. Next, read the transcript of the interview results carefully which was repeated several times. Simultaneously with these stages, the selection of the main themes contained in the transcript of the interview results was also carried out into the main statement. Next, group each main statement into a central theme. Compiling textural descriptions that contain descriptions of the phenomena being experienced by participants based on the main statements and central themes. Apart from compiling textural descriptions, structural descriptions are also arranged based on main statements and central themes. Structural descriptions that are compiled contain descriptions of participant responses in dealing with these phenomena. The last stage of analytic reduction is interpreting essence of all phenomena experienced by participants. The interpretation of the essence carried out in this phenomenological research is a combination of textural and structural descriptions that give a deep meaning to the phenomenon being experienced and the responses of the participants in dealing with these phenomena.

This phenomenological research method can be arranged in a scheme that facilitates the process of interpreting this research. The phenomenological research method scheme can be shown in Fig. 1.

Based on Fig. 1 it can be shown that this phenomenological research was conducted to explore the strategies of high school physics teachers in carrying out traditional gamebased learning during the Covid-19 pandemic. This phenomenological research was conducted by interviewing ten physics teachers from five public high schools in Yogyakarta. 


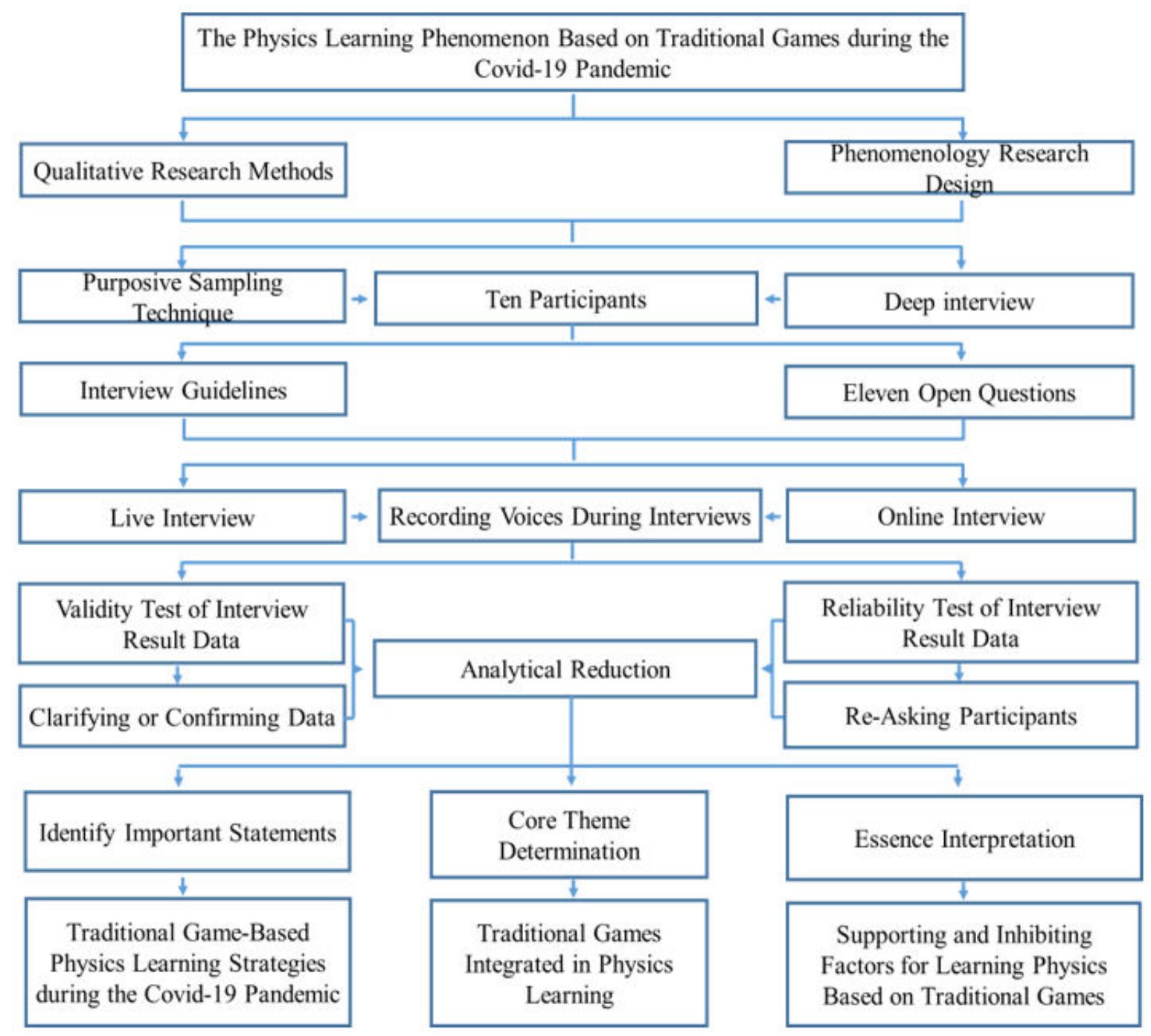

FIGURE 1. Schematic of the phenomenological research method.

The results of interviews with ten physics teachers were analyzed using analytic reduction techniques. It is through this analytical reduction that the strategy of middle-high school physics teachers in carrying out traditional gamebased learning during the Covid-19 pandemic can be identified.

\section{Result}

\subsection{Traditional game-based physics learning strategies during the Covid-19 pandemic}

The implementation of physics learning needs to be done in several stages so that the objectives of learning physics can be achieved. Especially now that all sectors of life are being hit by the Covid-19 pandemic, including the education sector, so it needs the right physics learning strategy. The physics learning strategy that needs to be done includes three stages, namely planning, implementing, and evaluating learning. Therefore, the following description will de- scribe the strategies undertaken by high school physics teachers in carrying out traditional game-based physics learning during the Covid-19 pandemic. The results showed that the physics learning strategy based on traditional games was different in each high school during the Covid-19 pandemic. WA stated that, "Learning physics during the Covid-19 pandemic feels so big a difference from learning physics before the Covid-19 pandemic. I must adapt to technology that supports learning during the Covid-19 pandemic. Since learning during the Covid-19 pandemic focused more on students, I did a contextual-based physics study". FA also carries out a physics learning strategy like WA, but FA carries out it's learning by integrating traditional games. The FA stated that, "During the Covid-19 pandemic, I taught physics to students by integrating traditional games and using the inquiry and project learning models. I ask students to find, create, and present traditional games that have physics concepts".

Physics learning in high schools during the Covid-19 pandemic needs to be done with a variety of models, methods, and activities of various students. This is done so that stu- 
dents can more easily understand the concepts of physics, considering that physics is one of the difficult subjects. This is by the WB statement that, "Physics is a difficult subject, so I teach physics material to students during the Covid19 pandemic using a contextual approach that is integrated with traditional games. I prepared in advance the traditional games that I would show the students". In addition to preparing physics learning media in the form of traditional games, there are also physics teachers who prepare from the planning, implementation, and evaluation stages of physics learning. This is by the argument presented by FB that, "I prepared an instructional design based on traditional games, traditional games, and evaluation sheets in the form of test questions. I do traditional game-integrated physics learning on a project-based basis. Project-based physics learning is carried out by asking students to create and present traditional games. My evaluation was done by assessing the task of making and presenting traditional games. I also give quizzes to assess the achievement of students' abilities".

There are also some teachers who not only integrate physics learning into traditional games, but into local potential. This is supported by FC's statement that, "During the Covid-19 pandemic, I asked students to find various physics concepts contained in the local wisdom that exists in their environment. I apply the inquiry learning model with the aim that students can apply the concepts of physics to life. Learning is carried out based on the instructional design that I have compiled, and I evaluate learning through the performance and learning outcomes of students". The argument presented by FC basically stated that physics learning carried out during the Covid-19 pandemic provided opportunities for students to explore deeply their cognitive, affective, and psychomotor abilities in the field of physics. Further, WC said that, "During the Covid-19 pandemic, my students still felt happy with physics learning that was carried out by integrating it into the physical phenomena that occurred in life. I asked each student about physics learning which is done by integrating it into traditional games and they answered that this time learning physics reminds them of the games they played when they were children". Based on these results, it shows that the integration of physics learning into traditional games is not only aimed at making it easier for students to learn physics concepts as well as preserving traditional games.

Learning physics during the Covid-19 pandemic provided an opportunity to apply a project-based learning model. This is because learning focuses on students. This is consistent with WD's statement which said that "I am more flexible in applying the project-based learning model, because students learn physics at home and have a longer time to complete the physics project that I provide. The physics project that I provide is to explore and record traditional games that exist in the social environment of students. After that, students choose one of the traditional games. Students then create and present these traditional games online. Other students respond to the presentation of physics concepts on traditional games". This shows that physics learning is not only done to optimize one student's ability, but physics learning is carried out to optimize all abilities of students which include cognitive, psychomotor, and affective abilities. Students who have followed physics learning are expected not only to highlight their cognitive abilities, but emphasize humanist, caring, dexterity, and innovative aspects. Furthermore, FD stated that, "During studying physics during the Covid-19 pandemic, I put more emphasis on students' concern for physical phenomena that occur in life. I ask students to find any phenomena that have more than one physics concept, especially in traditional games".

The integration of traditional games into physics learning during the Covid-19 pandemic aims to develop the innovation power and concern of students. This is by the statement conveyed by FE that, "Learning physics during the Covid-19 pandemic was carried out by integrating it into traditional games so that students were able to develop their innovative power. I give assignments to students to make traditional games by making some modifications, so that they can explain the concept of physics quantitatively. I give more portions to students to convey their ideas about traditional games related to physics concepts. The physics learning that I do uses a contextual learning model, inquiry, and problembased learning alternately". Meanwhile, evaluating physics learning during the Covid-19 pandemic can be done by developing various assessment instruments. This is by what WE stated that, "During the Covid-19 pandemic, I often did physics learning evaluations by assessing the results of students' independent assignments which included reports on making traditional game projects. I do this to find out all the abilities of students. I put more emphasis on virtual group discussions so that students share the knowledge they have". Thus, the strategy of high school physics teachers in carrying out traditional game-based physics learning during the Covid-19 pandemic can be arranged into a scheme as shown in Fig. 2.

Based on Fig. 2, it can be shown that the traditional game-based physics learning strategy in high schools during the Covid-19 pandemic was carried out by carefully preparing planning, implementing, and evaluating learning. Some of the arguments of high school physics teachers state that the implementation of physics learning based on traditional games during the Covid-19 pandemic needs to be prepared with a careful learning plan. The planning that needs to be prepared includes the preparation of an integrated instructional design with traditional games. The instructional design that is compiled is also able to accommodate the optimization of the cognitive, affective, and psychomotor aspects of students. The implementation of traditional game-based physics learning during the Covid-19 pandemic was carried out with contextual learning models, inquiry, projects, and problembased learning models. This is because physics learning focuses more on students as learning subjects. The evaluation of physics learning based on traditional games is carried out by assessing the performance, tests or quizzes, assignments, 


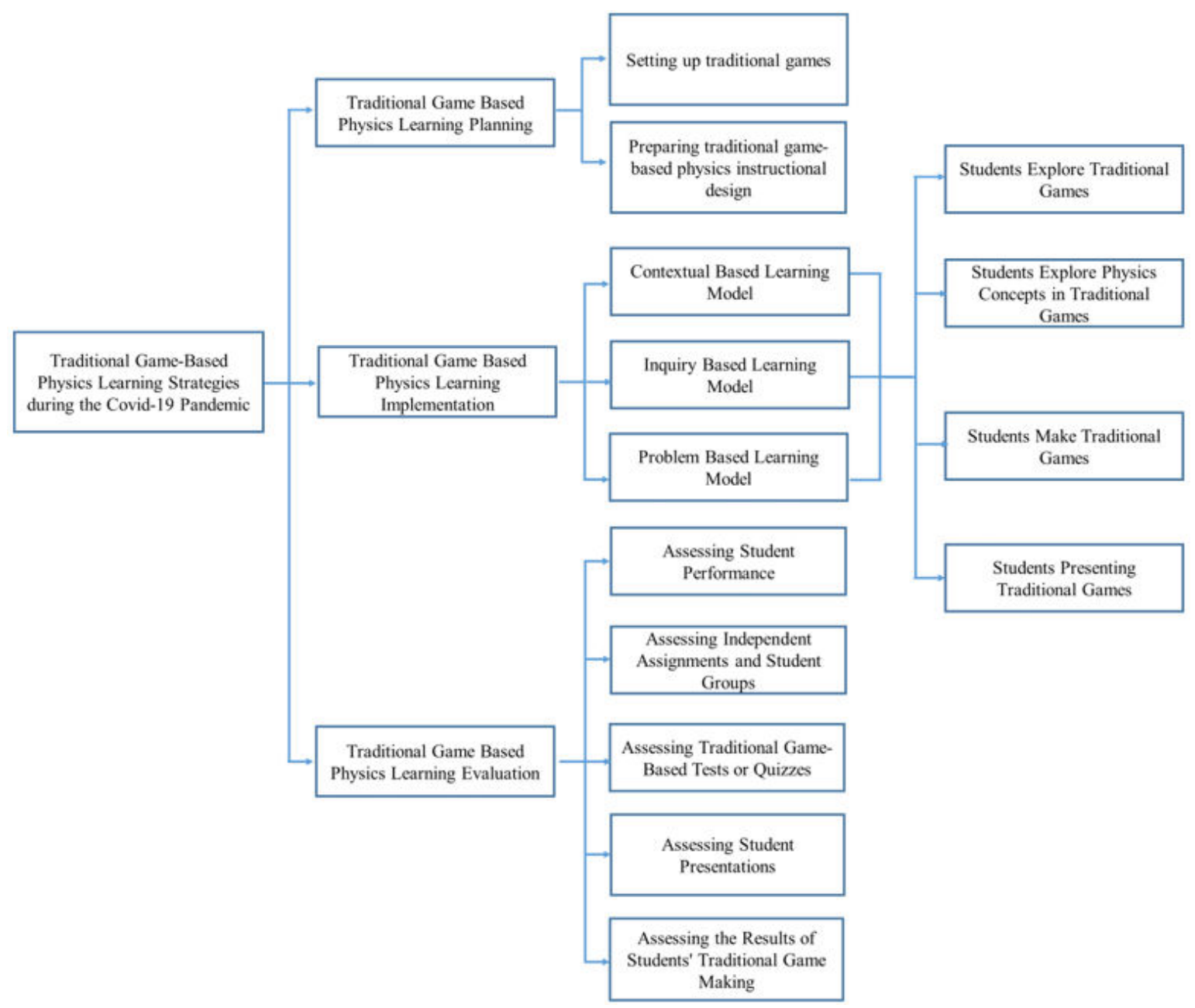

FIGURE 2. Traditional game-based physics learning strategies.

presentations, and the results of students' traditional game making projects.

\subsection{Traditional games integrated into physics learning}

Physics learning during the Covid-19 pandemic was carried out remotely and carried out at students' homes. Physics learning that is carried out at home provides flexibility for students to explore their abilities. Therefore, during the Covid-19 pandemic, many teachers conducted physics learning by integrating it into life as in traditional games. In addition to making, it easier for students to understand the concepts of physics, physics learning that is integrated into traditional games can also be used to preserve traditional games. This is by the statement put forward by WB that, "During the Covid-19 pandemic, I often taught students physics material by integrating it into traditional games. The traditional games that I often implement in physics learning are sulamanda games (a game of jumping on a pattern on the ground or floor), bekelan (the game of picking up objects and balls simultaneously by bouncing the ball), and gobak sodor (the game of knocking down an opponent on a certain path). I did this traditional game-integrated physics learning remotely with the help of the Zoom application".

Most high school physics teachers do not only integrate one traditional game in physics learning. This is by the statement submitted by the FA and WD that, "Learning physics during the Covid-19 pandemic, I often integrate into a variety of traditional games. Physics learning integrated into physics learning is done remotely via the Google Meet application. While the assignment, I did it through the Google Classroom application or WhatsApp. The traditional games I have integrated into learning physics include sulamanda (a game of jumping on a pattern on the ground or floor) and tulup (bamboo shooting game). I use the traditional sulamanda game because it is integrated with the concept of rigid equilibrium, motion, and the force of gravity. Blind game is used in physics learning because it contains the concepts of momentum and impulse, parabolic motion, and collisions". Physics learning during the Covid-19 pandemic can be done remotely through a distance learning application. This is as stated by FB, "The physics lessons that I conducted during the Covid-19 pandemic were conducted remotely by utilizing various supporting applications including Zoom and Google 


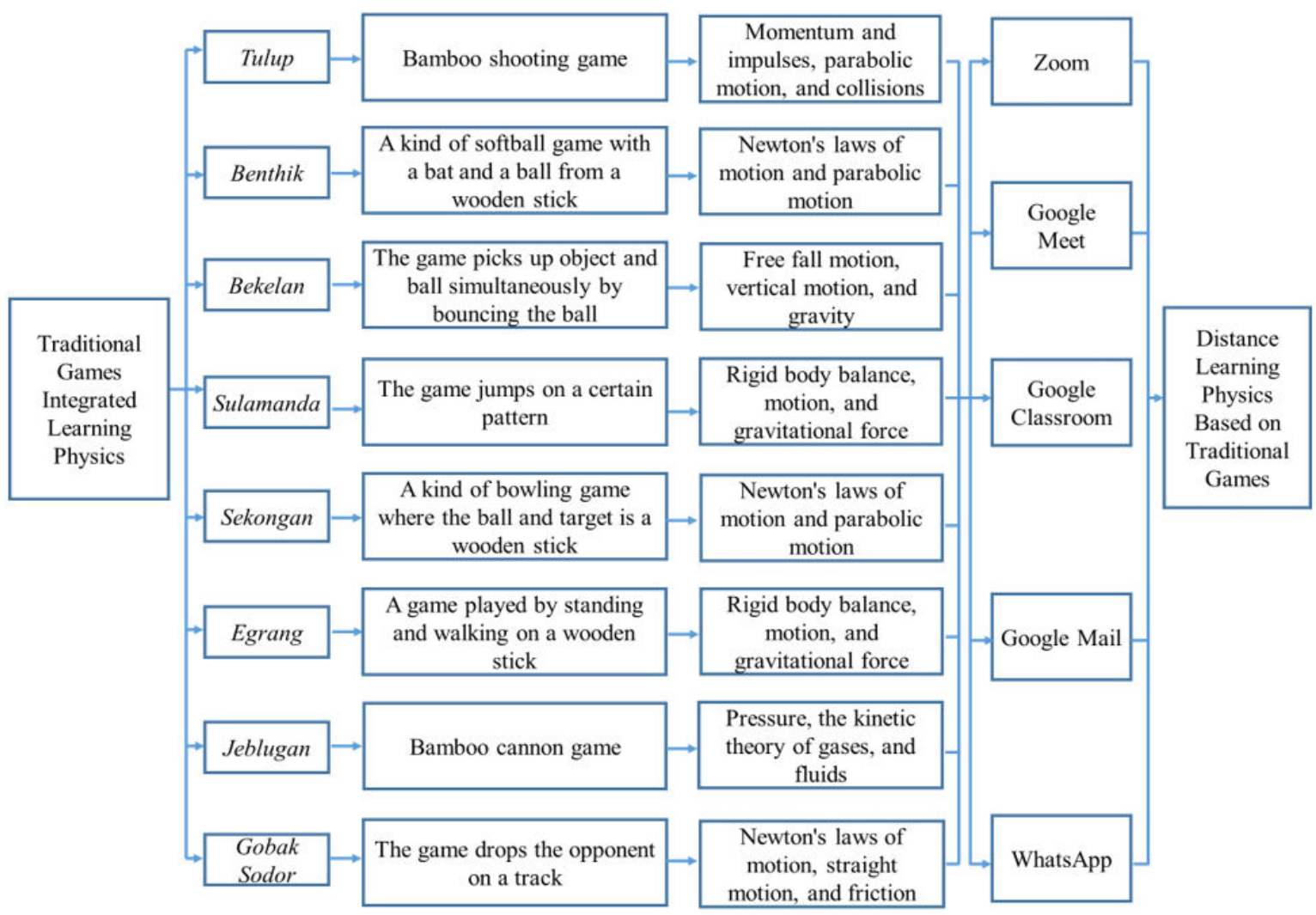

FIGURE 3. Traditional games integrated into physics learning.

Meet. I did my physics learning evaluation by sending assignments or asking students to send project progress via Google Mail or Google Classroom. I ask students to create traditional game development projects. The traditional games I assign to students include egrang (a game played by standing and walking on wooden sticks) and jeblugan (bamboo cannon game). I chose the egrang game because it has the concept of rigid body equilibrium, motion, gravitational force, and rotational momentum. I chose the jeblugan game because it can be used to explain the concept of pressure, $k i$ netic theory of gases, and fluids".

Most high school physics teachers in learning physics based on traditional games by asking students to demonstrate the game. This aims to make physics learning more meaningful and not just memorizing formulas. This is by the arguments stated by WA and FE that, "In doing traditional game-based physics learning, I often assign students to demonstrate traditional games through the help of Zoom and Google Meet. Traditional games demonstrated by students include bekelan and tulup games. Bekelan games were chosen because they can be used to help explain the concept of free fall, vertical motion, and gravity. Blind play can be used to explain the concepts of momentum and impulse". Learning physics is not just memorizing the formulas in the book, but requires students to be able to apply what they have learned in solving every physics phenomenon that occurs.

Some teachers ask students to videotape traditional games accompanied by explanations of physics concepts.
This is done considering that traditional games can only be played in a large open area. Physics learning as described above was carried out by FC and WC. FC and WC said that, "I asked students to record videos of the making and demonstration of traditional benthik and sekongan games. Traditional game video footage is presented via Zoom and sent via WhatsApp and Google Classroom. Benthik games (a kind of softball game with a bat and ball made of wooden sticks) and sekongan (a kind of bowling game where the ball and target are a wooden stick). I chose benthik and sekongan games because these two traditional games can be used to explain Newton's law concepts of motion and parabolic motion". Traditional game-based physics learning is carried out by giving various types of tasks aimed at optimizing the fighting power and creativity of students. This is by the statement conveyed by FD and WE that, "I do physics learning based on traditional games by giving assignments to students through Google Classroom to design, make, and present traditional games of egrang and tulup. I give this assignment to students with the hope that their creativity can develop properly". Thus, various traditional games integrated into physics learning can be arranged into a scheme as shown in Fig. 3.

Based on Fig. 3, it can be shown that various traditional games can be integrated into learning physics in high schools during the Covid-19 pandemic. Some of the arguments of high school physics teachers in Yogyakarta state that there are at least eight traditional games that are often integrated into learning. The eight traditional games include tulup (bamboo 
TABLE II. Traditional Games Used by Physics Teachers.

\begin{tabular}{ccccc}
\hline No. & $\begin{array}{c}\text { Traditional } \\
\text { Games }\end{array}$ & Teacher & Affiliation & $\begin{array}{c}\text { Total } \\
\text { Teacher }\end{array}$ \\
\hline 1. & Tulup & FA & PSHS-1 & 6 \\
& & WD & PSHS-4 & \\
& & WA & PSHS-1 & \\
& & FE & PSHS-5 & \\
& & FD & PSHS-4 & \\
2. & Benthik & WE & PSHS-5 & \\
& & FC & PSHS-3 & 2 \\
3. & Bekelan & WB & PSHS-3 & \\
& & WA & PSHS-1 & \\
& & FE & PSHS-5 & \\
4. & Sulamanda & WB & PSHS-2 & 3 \\
& & FA & PSHS-1 & \\
& & WD & PSHS-4 & \\
5. & Egrang & FB & PSHS-2 & 3 \\
& & FD & PSHS-4 & \\
& & WE & PSHS-5 & \\
6. & Sekongan & FC & PSHS-3 & 2 \\
& & WC & PSHS-3 & \\
7. & Jeblugan & FB & PSHS-2 & 1 \\
8. & Gobak Sodor & WB & PSHS-2 & 1 \\
\hline
\end{tabular}

shooting game), benthik (a kind of softball game with a bat and ball made of wooden sticks), bekelan (the game of picking up objects and the ball simultaneously by bouncing the ball), sulamanda (a game of jumping on a pattern. certain), egrang (a game played by standing and walking on wooden sticks), sekongan (a kind of bowling game where the ball and target is a wooden stick), jeblugan (bamboo cannon game), and gobak sodor (the game of dropping an opponent on a track). Meanwhile, the number of teachers who use traditional games as presented in Fig. 3 can be shown in Table II.

The eight traditional games can be used to explain more than one physics concept. Furthermore, this traditional gamebased physics learning is carried out by providing physics material and assignments to students through distance learning applications. The details of the teacher's number who use physics distance learning applications can be shown in Table III.

Based on Table III, physics teachers provide physics material and assignments to students through distance learning applications such as Zoom, Google Meet, Google Classroom, Google Mail, and WhatsApp. This was done considering the educational conditions affected by the Covid-19 pandemic, so face-to-face learning was replaced with distance learning.
TABLE III. Distance learning applications used by physics teachers.

\begin{tabular}{|c|c|c|c|c|}
\hline No. & Applications & Teacher & Affiliation & $\begin{array}{c}\text { Total } \\
\text { Teacher }\end{array}$ \\
\hline \multirow[t]{6}{*}{1.} & Zoom & WB & PSHS-2 & 6 \\
\hline & & FB & PSHS-2 & \\
\hline & & WA & PSHS-1 & \\
\hline & & FE & PSHS-5 & \\
\hline & & $\mathrm{FC}$ & PSHS-3 & \\
\hline & & WE & PSHS-3 & \\
\hline \multirow[t]{7}{*}{2.} & Google & FA & PSHS-1 & 7 \\
\hline & Meet & WD & PSHS-4 & \\
\hline & & FB & PSHS-2 & \\
\hline & & WA & PSHS-1 & \\
\hline & & $\mathrm{FE}$ & PSHS-5 & \\
\hline & & FB & PSHS-2 & \\
\hline & & WB & PSHS-2 & \\
\hline \multirow[t]{7}{*}{3.} & Google & FA & PSHS-1 & 7 \\
\hline & Classroom & WD & PSHS-4 & \\
\hline & & FB & PSHS-2 & \\
\hline & & $\mathrm{FC}$ & PSHS-3 & \\
\hline & & WC & PSHS-3 & \\
\hline & & FD & PSHS-4 & \\
\hline & & WE & PSHS-5 & \\
\hline 4. & Google Mail & FB & PSHS-2 & 1 \\
\hline \multirow[t]{4}{*}{5.} & WhatsApp & FA & PSHS-1 & 4 \\
\hline & & WD & PSHS-4 & \\
\hline & & $\mathrm{FC}$ & PSHS-3 & \\
\hline & & WC & PSHS-3 & \\
\hline
\end{tabular}

Note: every physics teacher uses more than one app.

\subsection{Supporting and inhibiting factors for learning physics based on traditional games during the Covid-19 pandemic}

The implementation of physics learning during the Covid19 pandemic certainly has various supporting and inhibiting factors that affect the success of learning. One of the factors that support traditional game-based physics learning during the Covid-19 pandemic is learning that is integrated into the daily experiences of students in traditional games. Meanwhile, one of the obstacles to learning physics based on traditional games during the Covid-19 pandemic was the different technological literacy abilities of students. This is by the statement submitted by the FA that, "During the Covid-19 pandemic, physics learning that I did by integrating traditional games made students enjoy learning more. This is because physics learning is carried out by integrating it into the daily life of students. Often my students experience interference with the internet signal while taking distance learning". 
Digital literacy needs to be developed during the Covid-19 pandemic, considering that physics learning can only be done remotely with the help of technological advances. If teachers and students cannot develop digital literacy skills, they will experience difficulties in carrying out distance learning. This is by the argument presented by WA that, "I have difficulty doing traditional game-based physics learning using distance learning applications. I realize that my digital literacy skills are still low".

For some teachers, distance learning physics during the Covid-19 pandemic was more efficient than face-to-face learning. This is because learning is carried out through computational technology that allows students to keep abreast of learning. The statement is by the opinion expressed by WB that, "I think physics learning based on traditional longdistance games is more efficient than face-to-face learning. This is because many students play and fall asleep during face-to-face learning. Distance learning physics also experiences various obstacles, such as students who do not have laptops, so they have to study with friends". Learning physics during the Covid-19 pandemic integrated into traditional games also saves education costs. This is because resources used in the learning process can be obtained from the environment of the student. Physics learning guidebooks are sent by the teacher in digital format for free. The statement is by FC's said that, "Traditional game-based physics learning during the Covid-19 pandemic can save education costs. This is because the learning resources used come from the environment where students live. Most of the tuition fees are allocated to buy internet quota, even though the internet network owned by students is unstable".

An unstable internet network is indeed one of the main problems in implementing distance learning. Not a few students climb the roof tiles to take distance learning physics. This is by the argument presented by FB that, "Many of my students experience problems with unstable internet networks. They told me that to take distance learning physics, they have to climb the roof tiles to get a stable internet signal. Even though there are obstacles in distance learning physics, distance learning can be done anywhere". Distance learning physics also focuses on learning on students, thus enabling teachers to carry out physics learning that involves a considerable portion of students. This is also what the WC does, the WC said that "During the Covid-19 pandemic, I often conducted student-centered physics learning by actively involving students in learning physics. The steps I take are implementing a project-based learning model. I ask students to complete a traditional game creation project".

In addition to the problem of an unstable internet network, distance learning is also considered less effective in optimizing the abilities of students. This is because students are not directly guided by the teacher in learning physics concepts. This is by the statement submitted by WD and FE that, "Most of the students do not understand the physics material that I explain. This is because they are not familiar with distance learning. This causes the implementation of physics learning on several subjects to be carried out slowly, given the ability of students to receive and process different physics material'. However, traditional game-based physics learning that is carried out remotely can also be carried out by the learning objectives that have been prepared. This is supported by the characteristics of distance learning physics which provide more time for students to explore their abilities. This is by the arguments presented by FD and WE that, "I often get stories about the experiences of students who carry out traditional game-based physics learning that is done remotely. They say that many new things they learn from the phenomena that occur around their lives. This is certainly one of the supporters of distance learning physics. Often students complain about limited facilities and a stable internet network when delivering their experiences or project presentations". Thus, the various factors supporting and inhibiting traditional game-based physics learning during the Covid-19 pandemic can be arranged into a scheme as shown in Fig. 4.

Based on Fig. 4, it can be shown that there are various supporting and inhibiting factors for learning physics based on traditional games during the Covid-19 pandemic. Some of the arguments of high school physics teachers in Yogyakarta state that the factors that support the implementation of physics learning based on traditional long-distance games include physics learning which saves educational costs, physics learning runs efficiently, physics learning can be done anywhere, it is easy for students to explore their abilities, and teachers can implement learning physics centered on students continuously. Meanwhile, factors that hinder learning physics based on traditional long-distance games include the low digital literacy skills of teachers and students, unstable internet networks, different abilities of students, unaccustomed distance learning physics, and limited facilities for supporting distance learning physics.

Meanwhile, the number of teachers who feel comfortable teaching physics remotely and teachers who are not comfortable teaching physics remotely can be shown in Table IV.

TABLE IV. Physics teachers impression of distance learning.

\begin{tabular}{|c|c|c|c|c|}
\hline \multirow{3}{*}{ Teacher } & \multirow{3}{*}{ Affiliation } & \multicolumn{2}{|c|}{ Physics Teachers } & \multirow{3}{*}{ Total } \\
\hline & & \multicolumn{2}{|c|}{ Impression } & \\
\hline & & Comfortable & Uncomfortable & \\
\hline FA & PSHS-1 & 1 & - & 6 \\
\hline $\mathrm{FC}$ & PSHS-3 & 1 & - & \\
\hline FD & PSHS-4 & 1 & - & \\
\hline WB & PSHS-2 & 1 & - & \\
\hline WC & PSHS-3 & 1 & - & \\
\hline WE & PSHS-5 & 1 & - & \\
\hline FB & PSHS-2 & - & 1 & 4 \\
\hline FE & PSHS-5 & - & 1 & \\
\hline WA & PSHS-1 & - & 1 & \\
\hline WD & PSHS-4 & - & 1 & \\
\hline
\end{tabular}




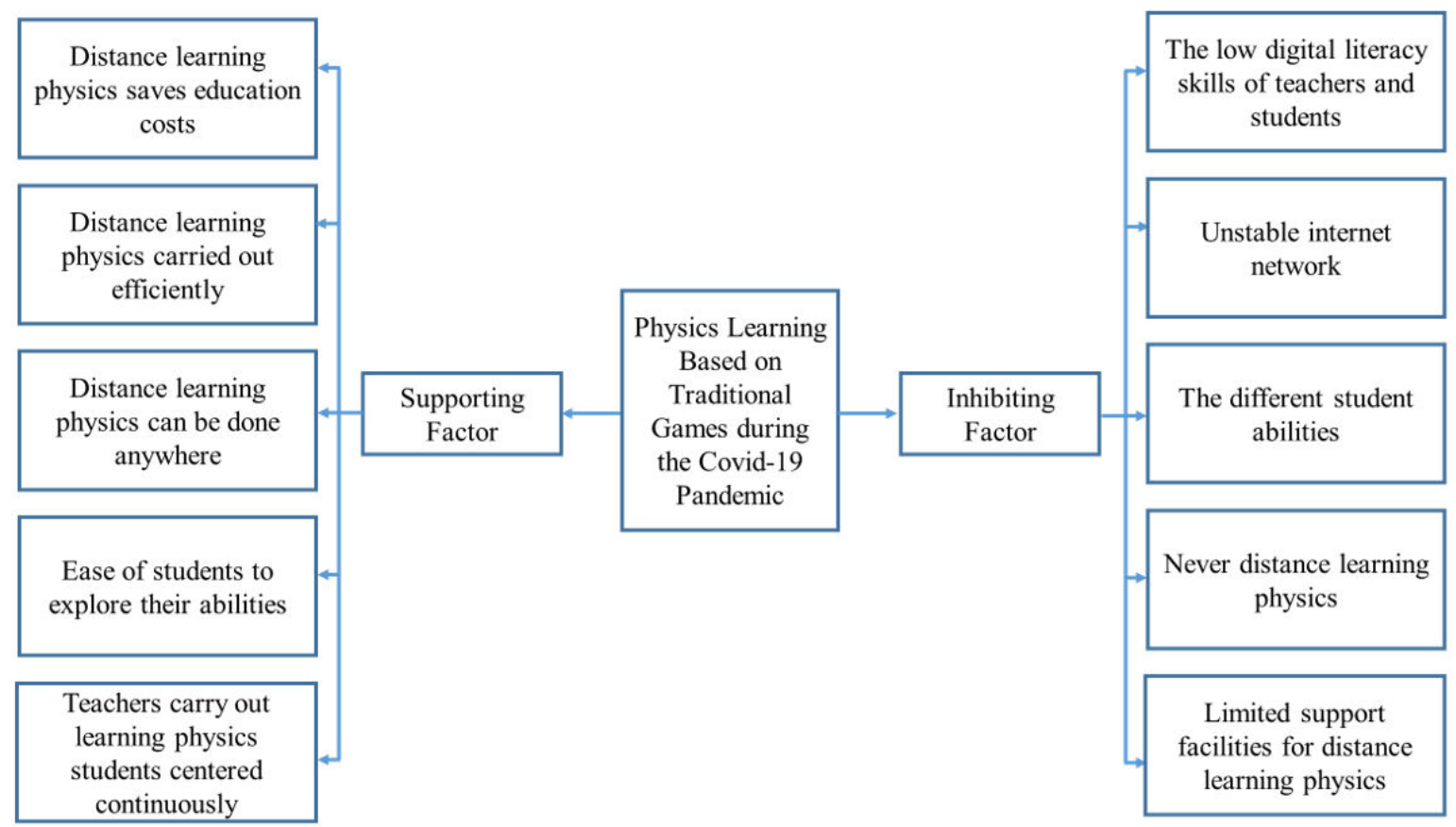

FIGURE 4. Supporting and inhibiting factors for learning physics based on traditional games.

Based on Table IV, most of the physics teachers, as many as six teachers feel comfortable teaching physics remotely. Meanwhile, four other physics teachers feel uncomfortable teaching physics remotely.

\section{Discussion}

During the Covid-19 pandemic, most of the physics learning was done remotely. This was done so that there was no more spread of Covid-19. In conducting distance learning physics, there are many innovations made by the teacher with the aim that students remain enthusiastic in learning physics. Besides, innovations made by physics teachers are also needed so that students can get meaningful learning. Learning is important for students to obtain because it serves as a tool to solve problems that occur in life [34]. However, there are still some physics teachers who do not make learning innovations. The physics teacher only explains physics concepts and gives assignments to students as written in a printed book [35]. This certainly raises its boredom in students studying physics. Besides, the student experience will not improve because learning is carried out focusing only on explaining formulas. This occurs because of various factors that influence it, such as teachers who cannot be adaptive to technology that supports learning and students who are used to teachercentered physics learning [36].

Another case was done by several high school physics teachers who were involved in this research. High school physics teachers in Yogyakarta during the Covid-19 pandemic conducted physics lessons by integrating them into the daily experiences of students. This is done to make it easier for students to understand the concepts of physics. Besides, integrating physics learning into life can also make it easier for students to apply physics concepts [37]. The implementation of physics learning by high school physics teachers in Yogyakarta is integrated into traditional games. Traditional games are chosen in integrating physics concepts because they are activities that are enjoyed by students. Activities that are liked by students if integrated into learning, students will be comfortable in learning and they are easy to understand the subject matter [38]. Besides, the integration of physics learning into traditional games is also carried out to preserve traditional games. By integrating physics learning into traditional games, it allows students to act as the center of physics learning activities. This is done considering that physics learning requires the active involvement of students [39]. This is done because physics is not just a subject to memorize formulas, but also applies physics concepts to answer phenomena that occur in life.

Physics learning integrated into traditional games is carried out so that students carry out their role as active learning subjects. The teacher needs to prepare a mature strategy for doing physics learning based on traditional long-distance games. The strategy that the teacher needs to prepare in carrying out traditional distance game-based physics learning includes planning a careful instructional design. Instructional design is a guideline for implementing learning [40]. If the instructional design is not detailed and systematic, likely the learning objectives cannot be achieved optimally. Besides, students' abilities also cannot develop according to the learning objectives that have been prepared [41]. Instructional designs prepared by the teacher are adapted to the innovations provided in learning such as traditional games. After the tra- 
ditional game-based instructional design has been arranged in detail and systematically, the teacher needs to prepare himself to adapt to technology that supports distance learning. Various reports stated that most teachers did not make learning innovations during the Covid-19 pandemic because they had difficulty using distance learning applications [42]. Therefore, every teacher needs to adapt to using distance learning applications.

Furthermore, the implementation of traditional gamebased physics learning is carried out by implementing a student-centered learning model. A learning model that is centered on students in learning, namely project-based learning [43]. Besides, contextual, and inquiry-based learning also focuses on learning for students [44]. In the implementation of traditional game-based physics learning which implements the project learning model, it allows students to understand and apply physics concepts. This is because students explore the physics concepts found in traditional games and make traditional games. In traditional game-based physics learning that implements the inquiry model, it is also able to optimize the students' inquiry abilities. In addition to the three learning models, the problem-based learning model also provides a larger portion of students. In other words, problembased learning requires the active involvement of students in learning [45]. In carrying out traditional game-based physics learning the teacher uses a student-centered learning model which also aims to accommodate students in exploring their abilities.

Physics learning that is carried out remotely is integrated into traditional games that are around the lives of students which consist of eight traditional games. The eight traditional games include tulup, benthik, bekelan, sulamanda, egrang, sekongan, jeblugan, and gobak sodor. The eight traditional games can be used to explain more than one physics concept. This shows that the physics concepts learned by students are a manifestation of phenomena that occur in life [46]. Physics learning needs to be integrated not only into traditional games, but into all activities carried out by students. Physics learning integrated into traditional games can be done anywhere as long as the distance learning support facilities are connected to an internet network. Meanwhile, integrating physics learning into traditional games requires all the abilities of students to work optimally. Learning physics that is integrated into traditional games do not only require cognitive aspects, but also affective and psychomotor aspects. This shows that learning integrated into everyday phenomena can develop students' cognitive abilities.

This is evidenced by the ability of students to answer physical phenomena that occur in life with the concept of physics [47]. In other words, students can explain various physics concepts through traditional games. The affective aspects of students can be increased through learning that is integrated into life [48]. Students become more concerned and respectful of phenomena, especially traditional games that exist in their environment [49]. In addition to the cognitive and affective aspects that can be improved, the psychomotor aspects of students can improve because they are directly involved in demonstrating traditional games [50]. Given that traditional game-based physics learning involves cognitive, affective, and psychomotor aspects of students, evaluation of the learning is carried out by assessing all aspects shown by students. Learning that is carried out holistically facilitates the achievement of meaningful learning [51]. Therefore, the evaluation of physics learning based on traditional games is carried out by assessing the performance, test results, presentations, and the work of students.

Although traditional game-based physics learning can provide opportunities for students to explore their abilities, several constraints hinder its implementation. Distance learning physics without direct guidance from the teacher causes students to be slow in understanding the concept of physics. Moreover, physics is a difficult subject for students. Even face-to-face physics learning is sometimes still difficult for students, let alone done remotely. Apart from that, distance learning also experiences constraints due to limited supporting facilities and an unstable internet network. This cannot be denied considering that Indonesia is a developing country whose education is not evenly distributed [52]. Many students have to learn to get to the roof tiles to get a stable internet network. Physics distance learning based on traditional games is often done slowly considering that teachers and students are not used to distancing learning. This causes distance learning to be less effective because it takes a long time. Coupled with the ability of students to receive and process different physics material. In the end, the steps taken by the teacher were by providing material and physics assignments to students, so that students often had misconceptions. Problems that hinder distance learning physics should immediately find a solution so that students can follow learning smoothly.

\section{Conclusion}

This research explores how traditional game-based physics learning strategies in high schools during the Covid-19 pandemic. The results showed that the strategy used in learning physics based on traditional long-distance games includes preparing instructional designs, implementing learning by implementing contextual-based learning models, inquiry, projects, and problem-based learning models. This is because physics learning focuses more on students as learning subjects. Traditional games in Yogyakarta that are integrated into physics learning include tulup, benthik, bekelan, sulamanda, egrang, sekongan, jeblugan, and gobak sodor games. These traditional games can be used to explain more than one physics concept. This learning is carried out by providing physics material and assignments to students through the help of distance learning applications such as Zoom, Google Meet, Google Classroom, Google Mail, and WhatsApp. Besides, some factors support traditional game-based physics learning, namely saving education costs, learning runs efficiently, learning can be done anywhere, it is easy 
for students to explore their abilities, and the teacher implements student-centered learning continuously. Factors that hinder learning physics based on traditional games include low digital literacy of teachers and students, unstable internet networks, different abilities of students, unfamiliarity with distance learning, and limited distance learning support facilities. While the contribution of this research is that physics learning is more meaningful if it is carried out by integrating it into the daily experiences of students. This is done so that students can solve problems that occur in life using the physics concepts that have been learned.

\section{Recommendation}

Based on the conclusions previously described, this research provides recommendations to students, teachers, further researchers, and the government. Students should optimize the opportunities for distance learning physics, considering that distance learning provides more time to explore the abilities of students. Students must create a fun physics learning atmosphere to make it easier to learn physics material. Physics teachers should not only implement physics learning into traditional games, but implement physics learning into all daily activities of students. Teachers must further improve digital literacy skills and the ability to adapt to technological advances. Further researchers can use the results of this research as a source of reference in researching learning physics during the Covid-19 pandemic. Besides, further researchers can carry out physics learning innovations by integrating them into traditional games based on android or virtual reality. Research is needed in every province in Indonesia. This aims to see the strategy of every physics teacher in
Indonesia in integrating traditional games into physics learning. Meanwhile, the government should start improving the quality of learning in Indonesia by providing internet quota assistance to students and providing free internet assistance to every village in Indonesia.

\section{Limitations}

This phenomenological research is carried out by complying with applicable research ethics, one of which is by disguising the identities of participants and affiliates. However, this research has limitations that can be fixed in future studies. The implementation of this research was limited to participants in the province of Yogyakarta, while the provinces in Indonesia were not only Yogyakarta. This phenomenological research produces findings that are as subjective as possible and applicable to the area where this research was carried out, so this research cannot be generalized broadly. Besides, this phenomenological research only focuses on traditional games, while the manifestation of local wisdom is not only in the form of traditional games, but also in the form of local potential.

\section{Acknowledgments}

We would like to thank the participants who were involved in this phenomenological research. We also express our gratitude to the lecturers and academic community of the Department of Educational Sciences, Graduate School, Universitas Negeri Yogyakarta who have supported the implementation of this phenomenological research.
1. R. Laurie, Y. Nonoyama-Tarumi, R. Mckeown, and C. Hopkins, Contributions of education for sustainable development (ESD) to quality education: A synthesis of research, J. Edu. Sust. Develop. 10 (2016) 226, https://doi.org/10.1177/ 0973408216661442

2. M. T. Hebebci, Y. Bertiz, and S. Alan, Investigation of views of students and teachers on distance education practices during the Coronavirus (COVID-19) Pandemic, Int. J. Tech. Edu. Sci. 4 (2020) 267, https://doi.org/10.46328/ijtes. v4i4.113

3. J. Scull, M. Phillips, U. Sharma, and K. Garnier, Innovations in teacher education at the time of COVID19: An Australian perspective, J. Edu. Teach. 46 (2020) 497, https : / / doi .org/ $10.1080 / 02607476.2020 .1802701$

4. M. D. Rahiem, The emergency remote learning experience of university students in Indonesia amidst the COVID-19 crisis, Int. J. Learn. Teach. Edu. Res. 19 (2020) 1, https://doi. org/10.26803/ijlter.19.6.1

5. P. C. Abrami, R. M. Bernard, E. M. Bures, E. Borokhovski, and R. M. Tamim, Interaction in distance education and online learning: Using evidence and theory to improve practice,
J. Comp. Higher Edu. 23 (2011) 82, https://doi.org/ $10.1007 / \mathrm{s} 12528-011-9043-\mathrm{x}$

6. Z. Qiang, A. G. Obando, Y. Chen, and C. Ye, Revisiting distance learning resources for undergraduate research and lab activities during the COVID-19 pandemic, J. Chem. Edu. 97 (2020) 3446, https://doi.org/10.1021/ acs.jchemed.0c00609

7. R. M. Simamora, The challenges of online learning during the COVID-19 pandemic: An essay analysis of performing arts education students, Stud. Learn. Teach. 1 (2020) 86, https: //doi.org/10.46627/silet.v1i2.38

8. R. R. Aliyyah, R. Rachmadtullah, A. Samsudin, E. Syaodih, M. Nurtanto, and A. R. S. Tambunan, The perceptions of primary school teachers of online learning during the COVID-19 pandemic period: A case study in Indonesia, J. Ethn. Cult. Stud. 7 (2020) 90, https://doi.org/10.29333/ejecs/388

9. Y. M. Huang, P. S. Chiu, T. C. Liu, and T. S. Chen, The design and implementation of a meaningful learningbased evaluation method for ubiquitous learning, Comput. Educ. 57 (2011) 2291, https://doi.org/10.1016/j. compedu.2011.05.023 
10. J. D. Karpicke and P. J. Grimaldi, Retrieval-based learning: A perspective for enhancing meaningful learning, Educ. Psychol. Rev. 24 (2012) 401, https://doi.org/10.1007/ s10648-012-9202-2.

11. C. L. Chiang and H. Lee, The effect of project-based learning on learning motivation and problem-solving ability of vocational high school students, Int. J. Info. Edu. Tech. 6 (2016) 709, https://doi.org/10.7763/IJIET.2016.V6.779

12. W. Wahyudi, B. Waluya, H. Suyitno, and I. Isnarto, The use of the 3CM (Cool-Critical-Creative-Meaningful) model in blended learning to improve creative thinking ability in solving a mathematics problem, J. Edu. Sci. Tech. 5 (2019) 26, https://doi.org/10.26858/est.v5i1.7852

13. E. Harianto et al., The compatibility of outdoor study application of environmental subject using psychological theories of intelligence and meaningful learning in senior high school, Geosf. Indones. 4 (2019) 201, https://doi.org/ 10.19184/geosi.v4i2.9903

14. S. C. Y. Hartatiti, A. Priambodo, B. Djawa, and B. B. Prakoso, Building cooperation interpersonal skills in physical education lessons through the traditional game, in Proceedings of the International on Publich Health and Education, Semarang, 2018 (Atlantis Press, Semarang, 2018), https://doi.org/10. $2991 /$ isphe-18.2018.57.

15. J. Schell, The art of game design: A book of lenses, 2nd ed. (CRC Press, Boca Raton, 2015).

16. J. Junaedah, S. B. Thalib, and M. A. Ahmad, The outdoor learning modules are based on traditional games in improving the prosocial behavior of early childhood, Int. Edu. Stud. 13 (2020) 73, https://doi.org/10.5539/ies.v13n10p88.

17. A. Putra and V. R. Hasanah, Traditional game to develop character values in a nonformal educational institution, Int. J. Adv. Edu. 4 (2018) 86, https://doi.org/10.18768/ ijaedu.415411

18. E. Nur'aeni, M. R. W Muharram, and S. Sriwianti, Didactical design of mathematics teaching based on gobak sodor traditional games in primary school, J. Phy.: Conf. Ser 1318 (2019) 012015, https://doi.org/10.1088/ 1742-6596/1318/1/012015

19. A. Echeverría, E. Barrios, M. Nussbaum, M. Améstica, and S. Leclerc, The atomic intrinsic integration approach: A structured methodology for the design of games for the conceptual understanding of physics, Comput. Educ. 59 (2012) 806, https://doi.org/10.1016/j.compedu.2012. 03.025 .

20. N. R. Dewi, F. Rizkiana, S. Nurkhalisa, and I. Dwijayanti, The effectiveness of Multicultural Education through traditional games-based inquiry toward improving the ability of critical thinking, J. Phy.: Conf. Ser. 1521 (2020) 042125. https : //doi.org/10.1088/1742-6596/1521/4/042125

21. Y. Allsop and J. Jessel, Teachers' experience and reflections on game-based learning in the primary classroom: Views from England and Italy, Int. J. Game Learn. 5 (2015) 1, https: //doi.org/10.4018/ijgbl.2015010101

22. S. Moser, J. Zumbach, and I. Deibl, The effect of metacognitive training and prompting on learning success in simulationbased physics learning, Sci. Edu. 101 (2017) 944, https: //doi.org/10.1002/sce.21295
23. M. Rodrigues and P. Simeão Carvalho, Teaching physics with Angry Birds: exploring the kinematics and dynamics of the game, Phys. Educ. 48 (2013) 431, https : / doi .org/10. 1088/0031-9120/48/4/431

24. E. Istiyono, W. S. B. Dwandaru, R. Setiawan, and I. Megawati, Developing computerized adaptive testing to measure physics higher-order thinking skills of senior high school students and its feasibility of use, Eur. J. Edu. Res. 9 (2020) 91, https: //doi.org/10.12973/eu-jer.9.1.91

25. S. Y. Erinosho, How do students perceive the difficulty of physics in secondary school? An exploratory study in Nigeria, Int. J. Cross-Discip. Subj. Educ. 3 (2013) 1510, https://doi.org/10.20533/ijcdse.2042. 6364.2013 .0212

26. I. Abrahams, M. Homer, R. Sharpe, and M. Zhou, A comparative cross-cultural study of the prevalence and nature of misconceptions in physics amongst English and Chinese undergraduate students, Res. Sci. Tech. Edu. 33 (2015) 111, https : //doi.org/10.1080/02635143.2014.987744

27. A. A. Putry, W. Warsono, S. Supahar, and J. Jumadi, Students and teachers' necessity toward multimedia learning modules (MLMs) based on Benthik local wisdom to provide students' physics initial knowledge, J. Phy. Conf. Ser. 1097 (2018) 012014, https://doi.org/10.1088/ 1742-6596/1097/1/012014

28. A. Setiawan, A. S. Nugraha, H. Haryanto, and I. Gamayanto, Benthix VR: A virtual reality simulation application to preserve traditional Benthik game, Com Tech 8 (2017) 183, https: //doi.org/10.21512/comtech.v8i4.4036

29. H. Soulé and T. Warrick, Defining 21 st-century readiness for all students: What we know and how to get there, Psy. Aest. Creat. Arts. 9 (2015) 178, https://doi.org/10.1037/ aca0000017

30. S. Klar and T. J. Leeper, Identities and intersectionality: A case for purposive sampling in survey-experimental research, in Experimental Methods in Survey Research: Techniques that Combine Random Sampling with Random Assignment, edited by P. Lavrakas, T. Traugott, C. Kennedy, A. Holbrook, E. de Leeuw, and B. West (John Wiley and Sons, New York, 2020), Chap. 21, https://doi.org/10.1002/ 9781119083771.ch21.

31. M. D. Vagle, Crafting phenomenological research, (Routledge, London, 2018).

32. M. B. Miles and A. M. Huberman, Qualitative data analysis: An expanded sourcebook, (SAGE Publications, California, 1994).

33. J. W. Creswell and J. D. Creswell, Research design: Qualitative, quantitative, and mixed Methods Approach, Sage. (SAGE Publications, California, 2017).

34. K. T. Dreifuerst, Getting started with a debriefing for meaningful learning, Clin. Simul. Nurs. 11 (2015) 268, https: //doi.org/10.1016/j.ecns.2015.01.005

35. V. Nivalainen, M. A. Asikainen, and P. E. Hirvonen, Open guided inquiry laboratory in physics teacher education, $J$. Sci. Teach. Educ. 24 (2013) 449, https://doi.org/10. 1007/s10972-012-9316-x. 
36. D. Dervić, D. S. Glamočić, A. Gazibegović-Busuladžić, and V. Mešić, Teaching physics with simulations: teacher-centered versus student-centered approaches, J. Baltic Sci. Edu. 17 (2018) 288, https://doi.org/10.33225/jbse/18. 17.288 .

37. E. W. Close, J. Conn, and H. G. Close, Becoming physics people: Development of integrated physics identity through the learning assistant experience, Phys. Rev. Phys. Educ. Res. 12 (2016) 010109, https://doi.org/10.1103/ PhysRevPhysEducRes.12.010109

38. Y. Jang, Convenience matters: A qualitative study on the impact of the use of social media and collaboration technologies on learning experience and performance in higher education, Educ. Inf. 31 (2015) 73, https://doi.org/10.3233/ EFI-150948

39. W. Wartono, M. N. Hudha and J. R. Batlolona, How are the physics critical thinking skills of the students taught by using inquiry-discovery through empirical and theoretical overview?, Eur. J. Math. Sci. Tech. Edu. 14 (2017) 691, https: // doi. org/10.12973/ejmste/80632

40. M. K. Khalil and I. A. Elkhider, Applying learning theories and instructional design models for effective instruction, Adv. Physiol. Educ. 40 (2016) 147, https://doi.org/10.1152/ advan.00138.2015

41. C.-J. Lee and C. Kim, An implementation study of a TPACKbased instructional design model in a technology integration course, Educ. Technol. Res. Dev. 62 (2014) 437, https:// doi.org/10.1007/s11423-014-9335-8

42. M. Churiyah, S. Sholikhan, F. Filianti, and D. A. Sakdiyyah, Indonesia education readiness conducting distance learning in Covid-19 pandemic situation, Int. J. Multicult. Multirelig. Underst. 7 (2020) 491, https://doi.org/10.18415/ i jmmu.v7i6.1833

43. A. Septian and S. Prabawanto, Mathematical representation ability through GeoGebra-assisted project-based learning models, J. Phys. Conf. Ser. 1657 (2020) 012019. https: / / doi. org/10.1088/1742-6596/1657/1/012019
44. A. Suárez, M. Specht, F. Prinsen, M. Kalz, and S. Ternier, A review of the types of mobile activities in mobile inquirybased learning, Comput. Educ. 118 (2018) 38, https:// doi.org/10.1016/j.compedu.2017.11.004.

45. E. Ceker and F. Ozdamli, Features and characteristics of problem-based learning, Cypriot J. Educ. Sci. 11 (2016) 195, https://doi.org/10.18844/cjes.v11i4.1296

46. L. Bigozzi, C. Tarchi, P. Falsini, and C. Fiorentini, 'Slow Science': Building scientific concepts in physics in high school, Int. J. Sci. Educ. 36 (2014) 2221, https://doi.org/10 . $1080 / 09500693.2014 .919425$

47. H. Putranta and S. Supahar, Development of physics-tier tests (PysTT) to measure students' conceptual understanding and creative thinking skills: A qualitative synthesis, $J$. Edu. Gift. Young Sci. 7 (2019) 747-775. https : / / doi .org/10. $17478 /$ jegys.587203

48. Y. Pantiwati and H. Husamah, Self and Peer Assessments in Active Learning Model to Increase Metacognitive Awareness and Cognitive Abilities, Int. J. Instr. 10 (2017) 45, https: //doi.org/10.12973/iji.2017.10411a

49. E. Suryawati and K. Osman, Contextual learning: Innovative approach towards the development of students' scientific attitude and natural science performance, Eurasia J. Math. Sci. Technol. Educ. 14 (2017) 61, https://doi.org/10. 12973/ejmste/79329

50. Y. Yuberti et al., Approaching problem-solving skills of momentum and impulse phenomena using context and problembased learning, Eur. J. Educ. Res. 8 (2019) 1217, https: //doi.org/10.12973/eu-jer.8.4.1217

51. M. Safdar, A. Hussain, I. Shah, and Q. Rifat, Concept maps: An instructional tool to facilitate meaningful learning, Eur. J. Edu. Res. 1 (2012) 55, https://doi.org/10.12973/ eu-jer.1.1.55

52. B. A. Olken, J. Onishi, and S. Wong, Should aid reward performance? Evidence from a field experiment on health and education in Indonesia, American Econ. J.: Appl. Econ. 6 (2014) 1, https://doi.org/10.1257/app.6.4.1 